Penelitian

\title{
Resistensi Enterobacteriaceae Terhadap Antibiotik Asal Sisa Makanan dari Sampah Pesawat di Bandara Internasional Soekarno Hatta
}

\author{
Enterobacteriaceae Resistance of Antibiotic from Left Over Food of Wastes in \\ International Flight at Soekarno Hatta International Airport
}

\author{
Julia Rosmaya Riasari'*, Mirnawati B. Sudarwanto ${ }^{2}$, Agustin Indrawati ${ }^{2}$, Hadri Latif ${ }^{2}$, \\ Navasuriya Radha Krishnan ${ }^{3}$, Herwin Pisestyani ${ }^{2}$ \\ ${ }^{1}$ Mahasiswa Program Studi Kesehatan Masyarakat Veteriner Sekolah Pascasarjana IPB \\ ${ }^{2}$ Staf Pengajar Program Studi Kesehatan Masyarakat Veteriner Sekolah Pascasarjana IPB \\ ${ }^{3}$ Mahasiswa Program Sarjana Fakultas Kedokteran Hewan IPB \\ *Penulis untuk korespondensi: julia.rosmaya@gmail.com \\ Diterima 26 Juli 2019, Disetujui 26 November 2019
}

\begin{abstract}
ABSTRAK
Sampah yang berasal dari pesawat internasional yang datang di Indonesia harus dimusnahkan tanpa kecuali dan berlaku untuk penerbangan dari negara manapun. Pemusnahan dilakukan untuk menghindari risiko penyebaran penyakit dari sampah yang dapat menyerang hewan, tumbuhan dan manusia. Aktivitas penumpang dari mancanegara, migrasi orang dan hewan dari satu negara ke negeri lain serta importasi makanan membuat bakteri yang terbawa masuk, termasuk bakteri yang resisten terhadap antibiotik dapat menyebar. Penelitian mengenai risiko masuknya bakteri resisten terhadap antibiotik melalui sampah pesawat belum pernah dilakukan. Untuk itu, penelitian ini bertujuan untuk mengetahui keberadaan bakteri resisten terhadap antibiotik pada sisa makanan dari sampel sampah internasional yang diambil dari Terminal 2D BISH. Hasil penelitian yaitu dari 78 sampel yang berasal dari 24 pesawat dan 2 perusahaan penyedia makanan pesawat (in-flight catering), didapatkan 53 sampel (67,95\%) positif Enterobacteriaceae. Hasil pengujian isolat resistensi Enterobacteriaceae terhadap antibiotik dalam sisa makanan penerbangan internasional menunjukkan tingkat resistensi yang cukup tinggi, yaitu: Nalidixic Acid (57\%), Cefoxitin (32\%), Ampicillin (26\%), Amoxicillin (15\%), Tetracycline (9\%), Cefotaxime (5\%), Kanamycin (3\%), dan terendah adalah Sulfatrimethoprim (1\%). Selain itu, bakteri Enterobactriaceae ini juga menunjukkan tingkat intermediate terhadap antibiotik Cefotaxime (37\%), Cefoxitin (13\%), Tetracycline (6\%), Kanamycin (6\%), Amoxicillin (4\%), Nalidixic Acid (4\%), Sulfatrimethoprim (2\%), dan Ampicillin (0\%).
\end{abstract}

Kata kunci: sampah pesawat, Enterobacteriaceae, bakteri, resisten antibiotik

\begin{abstract}
More and more human and animal travel from country to country, alongside with the increasing number of animal goods importation. These are carries the risk of entering antibiotic-resistant bacteria from other country to Indonesia. Aircraft garbage from international flight of any country must be destroyed. The risk of spreading disease through international waste is present and cannot be ignored. The aim of this research is to know the presence of antibioticresistance bacteria from left-over food in international waste through Soekarno Hatta International Airport. Of 78 samples, 53 samples $(67,95 \%)$ were found to be positive for Enterobacteriaceae. The result from antibiotic-resistant bacteria test shows a high level of antibiotic-resistant, which are Nalidixic Acid (57\%), Cefoxitin (32\%), Ampicillin (26\%), Amoxicillin (15\%), Tetracycline (9\%), Cefotaxime (5\%), Kanamycin (3\%), and the lowest is Sulfatrimethoprim (1\%). The Enterobacteriaceae from sample also shows the intermediate resistant level of antibiotic, which are Cefotaxime (37\%), Cefoxitin (13\%), Tetracycline (6\%), Kanamycin (6\%), Amoxicillin (4\%), Nalidixic Acid (4\%), Sulfatrimethoprim (2\%), and Ampicillin (0\%).
\end{abstract}

Keywords: aircraft wastes, Enterobacteriaceae, antibiotic-resistance, bacteria 


\section{PENDAHULUAN}

Sampah Internasional (SI) merupakan istilah yang diberikan pada sampah dari pesawat atau kapal laut internasional (CFIA 2012). Sisa makanan dari pesawat yang mengandung bahan asal hewan, ikan, dan tumbuhan memiliki risiko menyebarkan penyakit ke hewan dan manusia. Produk pangan asal hewan, ikan dan tumbuhan yang diserahkan penumpang ke petugas di bandara sebelum keluar juga termasuk di dalam definisi ini. Seluruh SI harus diperlakukan secara khusus, sejak datang hingga dimusnahkan. Bahkan di beberapa negara seperti Amerika Serikat, Kanada, dan Australia, SI tidak diperkenankan diturunkan dari pesawat/kapal internasional karena mengandung risiko penyebaran penyakit pada hewan dan tumbuhan (CFIA 2012).

Beberapa penyakit seperti penyakit mulut dan kuku, African swine fever, hog cholera, dan African horse sickness belum ditemukan di Indonesia. Kemungkinan penyakit-penyakit tersebut dapat masuk ke Indonesia melalui SI. Menurut Kulczyński et al. (2017), penyakit pencernaan pada penumpang pesawat biasanya dihubungkan dengan makanan dari pesawat (in-flight catering) itu sendiri baik penyebabnya food-borne, water-borne, atau airborne bila ada penumpang yang sakit. Penyakit tular pangan (food-borne disease) yang umum ditemui pada penumpang pesawat udara adalah salmonellosis. Hingga tahun 2005, terdapat lebih dari 15 kasus salmonellosis pada penumpang pesawat internasional di Polandia. Sedangkan kasus shigellosis dan keracunan makanan akibat bakteri Staphylococcus jarang terjadi (Kulczyński et al. 2017).

Sampah internasional berdasarkan UndangUndang Nomor 16 Tahun 1992 mengenai Karantina Hewan, Ikan, dan Tumbuhan merupakan bagian dari media pembawa lain (MPL). Definisi MPL hewan adalah peralatan bekas pakai dan sampah karantina hewan yang diturunkan dari alat angkut di tempat pemasukan dan tempat transit. Sampah karantina hewan terdiri dari sisa-sisa makanan penumpang yang mengandung bahan asal hewan atau produk asal hewan yang tidak memenuhi persyaratan karantina, dan terlanjur dibawa ke tempat pemasukan, serta sisa makanan hewan, dan kotoran hewan. Badan Karantina Pertanian Kementerian Pertanian bertanggung jawab terhadap pengawasan sampah karantina di bandara ataupun pelabuhan laut. Pada pasal 25, UU Nomor 16 tahun 1992 tentang Karantina Hewan, Ikan dan Tumbuhan menerangkan bahwa MPL yang terbawa oleh alat angkut dan diturunkan di tempat pemasukan harus dimusnahkan oleh pemilik alat angkut yang bersangkutan di bawah pengawasan petugas karantina.

Bandara Internasional Soekarno Hatta (BISH) merupakan bandara tersibuk di Indonesia baik untuk penerbangan domestik maupun internasional. Bandara memiliki potensi besar dan pengaruh substansial dalam hal produksi sampah yang dihasilkan dari aktivitas di terminal, kargo, perkantoran, pertamanan, dan pesawat udara. Peningkatan penumpang akan meningkatkan sampah dari pesawat ataupun dari lingkungan bandara (BPS 2017).

Berdasarkan penelitian yang dilakukan oleh Adiati dan Rahardyan (2012) diketahui jumlah sampah di BISH adalah $0.121 \mathrm{~kg} /$ penumpang/hari. Sampah tersebut terdiri dari 35\% kertas, $26 \%$ plastik, $19 \%$ sisa makanan, dan sisanya adalah sampah tetrapak, kaleng, dan alumunium foil, sampah taman, dan material lain seperti kayu dan karet. Jumlah sampah di BISH pada tahun 2011 mencapai 22.42 ton/hari. Dari total jumlah sampah BISH tersebut, 8ton atau seki$\operatorname{tar} 34 \%$ diantaranya merupakan sampah pesawat. Sampah pada tahun 2011 sebesar 22.42 ton/hari ini akan meningkat menjadi 40.13 ton/hari pada kapasitas pelayanan bandara sebesar 62 juta penumpang pertahun. Sampah pesawat sendiri akan mencapai 10 ton/hari atau meningkat menjadi $41 \%$ dari total sampah bandara.

Data dari International Air Transport Association (IATA), penumpang pesawat meninggalkan sampah seberat $0.82-2.5 \mathrm{~kg}$ atau rerata $1.43 \mathrm{~kg}$ per orang, tergantung pada jarak dan waktu perjalanan, Dari jumlah tersebut, $23 \%$ adalah sisa makanan yang tidak dimakan penumpang, dan $17 \%$ adalah sampah yang dapat didaur ulang (plastik, botol, koran bekas) (IATA 2014)

Sampah pesawat dapat berupa atau diduga mengandung produk hewan dan atau produk asal hewan (daging, keju, susu, krim) yang berasal dari katering pesawat atau bawaan penumpang. Sampah pesawat harus diperlakukan khusus tanpa memandang negara asal pesawat (CFIA 2012). Sisa makanan tersebut dapat berupa bahan sisa atau bentukan utuh yang tidak layak makan lagi. Adanya kemungkinan sampah mengandung bakteri patogen dan non patogen tidak dapat diabaikan. Penumpang dari luar negeri dapat membawa masuk bakteri resisten antibiotik dari makanan dan lingkungan asalnya. Terutama penumpang yang berasal dari negara yang memiliki tingkat resistensi tinggi terhadap antibiotik.

Obat-obatan mengandung antibiotik yang masuk ke saluran pembuangan terkadang tidak dapat didegradasi atau dimusnahkan selama proses pe- 
ngolahan limbah. Air limbah yang mengandung antibiotik tersebut dapat mencemari air permukaan, air tanah dan air minum, serta kolam atau saluran air tempat ikan berkembang biak. Sisa antibiotik yang digunakan oleh peternakan sebagai obat atau sebagai pendukung pertumbuhan disekresikan oleh hewan ternak dan berakhir sebagai pupuk kandang. Pupuk kandang digunakan di pertanian untuk menyuburkan tanaman. Antibiotik yang terkandung dalam pupuk kandang dapat mencemari tanah dan air permukaan (Kümmerer 2003). Semakin meningkatnya aktivitas penumpang dari mancanegara, migrasi orang dan hewan dari satu negara ke negara lain serta importasi makanan membuat bakteri resisten antibiotik yang terbawa dapat menyebar semakin luas ke seluruh dunia. Berdasarkan analisa tersebut, terdapat kemungkinan bakteri resisten antibiotik dari sampah pesawat dapat mencemari lingkungan. Penelitian mengenai hal tersebut belum pernah dilakukan. Untuk itu, penelitian ini bertujuan untuk mengetahui bakteri resistensi terhadap antibiotik dari sisa makanan pada sampah internasional di BISH.

\section{BAHAN DAN METODE}

\section{Waktu dan Tempat Penelitian}

Penelitian ini dilakukan pada bulan Febuari hingga Desember 2018. Sampel diambil saat pengawasan rutin Balai Besar Karantina Pertanian Soekarno Hatta di Terminal 2D BISH. Pengujian dilakukan di beberapa tempat, yaitu (1) isolasi, identifikasi Enterobacteriaceae, dan pengujian resistensi bakteri terhadap antibiotik dilakukan di Laboratorium Kesehatan Masyarakat Veteriner Fakultas Kedokteran Hewan Institut Pertanian Bogor, (2) konfirmasi Enterobacteriaceae menggunakan kit API di Laboratorium Kesehatan Masyarakat Veteriner Fakultas Kedokteran Hewan Institut Pertanian Bogor dan Balai Pengujian Mutu dan Sertifikasi Produk Hewan (BPMSPH) Bogor, (3) konfirmasi Salmonella menggunakan uji PCR di Laboratorium Terpadu Fakultas Kedokteran Hewan Institut Pertanian Bogor.

\section{Metode Pengambilan Sampel}

Sampel yang diambil adalah sampah dari penerbangan luar negeri yang tiba di pelataran pesawat Terminal 2D. Sampah yang dimaksud meliputi sisa makanan/minuman asal hewan dan produk hewan serta kemasan dari sisa makanan tersebut. Pengambilan sampel dilakukan sesaat se- telah sampah dikeluarkan dari pesawat dan pada sampah makanan yang dikelola oleh petugas katering pesawat. Pengambilan sampel dilakukan berdasarkan SNI 19-3964-1994 mengenai Metode pengambilan dan pengukuran contoh timbulan dan komposisi sampah perkotaan (BSN 1994). Pengambilan sampel dilakukan selama 8 hari berturut-turut pada lokasi yang sama dengan waktu yang berbeda.

\section{Isolasi dan Identifikasi Enterobacteriaceae}

Pengujian dilakukan berdasarkan SNI 2897-2008 mengenai metode pengujian cemaran mikroba dalam daging, telur, dan susu, serta hasil olahannya. Sebanyak $25 \mathrm{~g}$ sampel dicairkan pada $225 \mathrm{ml}$ 0.1\% Buffered Peptone Water (BPW) dan dihomogenkan menggunakan stomacher. Kemudian $10 \mathrm{ml}$ dari larutan dipindahkan ke tabung reaksi steril dan diinkubasi selama 24 jam pada suhu $37^{\circ} \mathrm{C}$. Selanjutnya ditumbuhkan pada media agar Mac Conkey serta diinkubasi pada suhu $37^{\circ} \mathrm{C}$ selama 24 jam. Koloni yang tumbuh diamati kemudian dimurnikan dalam agar Mac Conkey serta diinkubasi kembali pada suhu 37 ${ }^{\circ} \mathrm{C} \pm 1{ }^{\circ} \mathrm{C}$ selama 24 jam. Isolat tunggal yang sudah didapat kemudian dikonfirmasi secara biokimia menggunakan uji IMVIC yaitu indol (tryptone), Methyl Red-Voges Proskauer (MR-VP), Koser's Citrate (KC) broth. Juga dilakukan pengujian menggunakan media agar sulfide, indole, motility (SIM); Lauryl Sulphat Tryptose Broth (LSTB); dan agar Levine EosinMethylene Blue (LEMB).

Isolat terduga, kemudian diuji menggunakan kit API 20E (Biomereaux). Penyegaran isolate dilakukan dengan kultur pada TSB yang diinkubasi pada suhu $37^{\circ} \mathrm{C}$ selama 24 jam, kemudian dikultur pada TSA yang diinkubasi pada suhu $37^{\circ} \mathrm{C}$ selama 24 jam. Dari koloni terpisah, 2-5 koloni diambil dengan swab steril dan dicampur ke dalam $5 \mathrm{ml} 0.85 \% \mathrm{NaCL}$ steril sampai kekeruhan sama dengan MacFarland 0.5 atau setara dengan 1-2 x $108 \mathrm{CFU} / \mathrm{ml}$. Suspensi bakteri kemudian diaplikasikan ke dalam kit uji API $20 \mathrm{E}$ (Biomereaux) dan diinkubasi pada suhu $37^{\circ} \mathrm{C}$ selama 24 jam. Pembacaan hasil tes dengan menggunakan kit uji API 20E (Biomereaux) dilakukan melalui aplikasi APIWEB ${ }^{\text {TM }}$ (API 2018).

Untuk isolasi dan identifikasi Salmonella, $25 \mathrm{~g}$ sampel dicairkan dalam $225 \mathrm{ml}$ 0.1\% BPW dan dihomogenkan menggunakan stomacher. Sepuluh (10) ml larutan yang homogen dipindahkan ke tabung reaksi steril dan diinkubasi selama 24 jam pada suhu $37{ }^{\circ} \mathrm{C}$. Larutan tersebut kemudian dikultivasi dalam Rappaport Vassiliadis Broth (RV) dan diinkubasi dalam waterbath selama 24 jam pada suhu $42{ }^{\circ} \mathrm{C}$. 
Setelah 24 jam, larutan digoreskan pada agar Xylose Lysine Deoxycholate (XLD) dan diinkubasi pada kondisi aerobik selama 24 jam pada suhu $37^{\circ} \mathrm{C}$. Koloni berbentuk bulat dengan ukuran 1.1-1.5 mm (lebar) and 2.0-2.6 mm (panjang), berwarna merah muda dengan atau tanpa titik hitam; atau koloni berwarna hitam dapat diduga sebagai Salmonella spp. Koloni terduga sebagai Salmonella spp kemudian dikonfirmasi menggunakan uji PCR (BSN 2008).

\section{Pengujian Resistensi Bakteri terhadap Antibiotik}

Isolat Enterobacteriaceae diremajakan dalam media Tryptone Soya Agar (TSA) dan diinkubasi pada suhu $35^{\circ} \mathrm{C}$ selama 24 jam. Isolat Enterobacteriaceae yang sudah murni diambil kemudian dimasukkan ke dalam media Tryptone Soya Broth (TSB). Suspensi bakteri diinkubasi ke dalam inkubator $35^{\circ} \mathrm{C}$ selama 0.5-2 jam, setiap 0.5 jam diperiksa tingkat kekeruhan suspensi bakteri setara dengan kekeruhan 0.5 McFarland ( $1.5 \times 108 \mathrm{CFU} / \mathrm{ml})$. Selanjutnya isolat bakteri digoreskan secara merata di atas media MHA mengunakan cotton bud steril. Cakram antibiotik diletakkan di atas permukaan MHA menggunakan disc dispenser setelah permukaan agar kering. Selanjutnya diinkubasi pada suhu $35^{\circ} \mathrm{C}$ selama 20-24 jam.
Pengukuran diameter zona hambat dilakukan setelah 24 jam. Penentuan kategori susceptible, intermediet, dan resistance ditentukan melalui ukuran daya hambat yang terbentuk berdasarkan standar Clinical and Laboratory Standard Institute (CLSI, 2016) seperti yang tergambarkan pada tabel 1 (Janet 2018).

\section{HASIL}

Dari 78 sampel yang berasal dari 24 pesawat dan 2 perusahaan penyedia makanan pesawat (in-flight caterings) didapatkan 53 sampel (67.95\%) positif Enterobacteriaceae. Uji konfirmasi menggunakan Kit API 20E (Biomereaux) ditemukan ditemukan 5 spesies bakteri yaitu Enterobacter cloaca, Ochrobactrum anthropi, Ewingella americana, Providencia rettgeri, dan Chronobacter spp. Uji konfirmasi menggunakan PCR pada 1 sampel terduga Salmonella spp didapatkan Salmonella enterica serovar Typhimurium (Salmonella Typhimurium). Cronobacter spp, Enterobacter cloaca, dan Providencia rettgeri pada penelitian ini ditemukan pada sampel daging ayam. Ochrobactrum anthropi ditemukan di krim. Ewingella americana pada daging dan Salmonella Typhymurium pada keju, seperti yang terlihat pada Tabel 2.

Tabel 1 Standar interpretasi diameter zona hambat (CLSI 2016)

\begin{tabular}{|c|c|c|c|c|c|}
\hline \multirow{2}{*}{$\begin{array}{l}\text { Golongan Antibiotik } \\
\text { Berdasarkan Struktur } \\
\text { Kimia }\end{array}$} & \multirow{2}{*}{ Antibiotik } & \multirow{2}{*}{$\begin{array}{c}\text { Isi } \\
\text { Cakram } \\
\text { ( } \mu g)\end{array}$} & \multicolumn{3}{|c|}{$\begin{array}{l}\text { Standar Interprestasi Zona Hambat } \\
(\mathrm{mm})\end{array}$} \\
\hline & & & $\mathrm{R}$ & I & $\mathrm{S}$ \\
\hline \multirow{2}{*}{ Penicillin } & Amoxicillin & 100 & $<13$ & $14-16$ & $>17$ \\
\hline & Ampicillin & 100 & $<13$ & $14-16$ & $>17$ \\
\hline Tetracycline & Tetracycline & 100 & $<14$ & $15-18$ & $>19$ \\
\hline \multirow{2}{*}{ Cephalosporin } & Cefotaxime & 100 & $<14$ & $15-17$ & $>18$ \\
\hline & Cefoxitin & 100 & $<21$ & & $>22$ \\
\hline Aminoglycoside & Kanamycin & 100 & $<13$ & $14-16$ & $>18$ \\
\hline Fluoroquinolone & Nalidixic Acid & 100 & $<13$ & $14-18$ & $>19$ \\
\hline Sulfonamides & Sulfatrimethoprim & 100 & $<10$ & $11-15$ & $>16$ \\
\hline
\end{tabular}

Keterangan: $\mathrm{R}=$ Resistant; I= Intermediate; $\mathrm{S}=$ Sensitive

Tabel 2 Identifikasi Enterobacteriaceae yang diisolasi dari sampel pangan asal hewan pada sampah intenasional di BISH

\begin{tabular}{clc}
\hline No & \multicolumn{1}{c}{ Genus/Spesies } & Sampel pangan asal hewan \\
\hline 1 & Enterobacter cloaca & Ayam \\
2 & Ochrobactrum anthropic & Krim \\
3 & Ewingella Americana & Daging \\
4 & Providencia rettgeri & Ayam \\
5 & Chronobacter spp & Ayam \\
6 & Salmonella Typhimurium & Keju \\
\hline
\end{tabular}


Tabel 3 Hasil uji resistensi Enterobacteriaceae dalam sampel sisa makanan terhadap antibiotik

\begin{tabular}{lllllllll}
\hline & NDA & FOX & AMP & AMX & TCE & CTX & KMC & SXT \\
\hline Resisten (\%) & 57 & 32 & 26 & 15 & 9 & 5 & 3 & 1 \\
Intermediat (\%) & 4 & 13 & 0 & 4 & 6 & 37 & 6 & 2 \\
Sensitif (\%) & 57 & 55 & 74 & 81 & 85 & 58 & 91 & 97 \\
\hline
\end{tabular}

Keterangan: Amoxicillin (AMX), Ampicillin (AMP), Tetracycline (TCE), Cefotaxime (CTX), Cefoxitin (FOX), Kanamycin (KMC), Nalidixic Acid (NDA), Sulfatrimethoprim (SXT)

Hasil pengujian isolat resistensi Enterobacteriaceae terhadap antibiotik dalam sisa makanan penerbangan internasional menunjukkan tingkat resistensi yang cukup tinggi seperti yang terlihat pada tabel 2, yaitu; Nalidixic Acid (57\%), Cefoxitin (32\%), Ampicillin (26\%), Amoxicillin (15\%), Tetracycline (9\%), Cefotaxime (5\%), Kanamycin (3\%), dan terendah adalah Sulfatrimethoprim (1\%). Selain itu, bakteri Enterobactriaceae ini juga menunjukkan tingkat intermediate terhadap antibiotik Cefotaxime (37\%), Cefoxitin (13\%), Tetracycline (6\%), Kanamycin (6\%), Amoxicillin (4\%), Nalidixic Acid (4\%), Sulfatrimethoprim (2\%), dan Ampicillin (0\%).

Enterobacteriaceae MDR yang berasal dari sisa makanan penerbangan international telah resisten terhadap 1 golongan antibiotik (49\%), 2 golongan antibiotik (38\%), 3 golongan antibiotik (10\%), dan 4 golongan antibiotik (3\%).

\section{PEMBAHASAN}

Sampah penerbangan adalah sampah berupa atau diduga mengandung produk hewan atau sisasisanya yang berasal dari makanan yang dihidangkan di dalam pesawat atau sebagai hasil transportasi hewan menggunakan pesawat. Ketentuan ini berlaku untuk penerbangan dari negara manapun (CFIA 2012). Ketentuan yang berhubungan dengan sampah sisa penerbangan dalam pasal 25 UU Nomor 16 tahun 1992 mengenai Karantina Hewan, Ikan, dan Tumbuhan, bahwa sampah yang terbawa oleh alat angkut dan diturunkan di tempat pemasukan harus dimusnahkan oleh pemilik alat angkut yang bersangkutan di bawah pengawasan petugas karantina. Sampah dari pesawat apapun jenisnya, harus diperlakukan berbeda dengan sampah dari terminal, perkantoran, atau lingkungan seputar bandara. Perhatian lebih harus diberikan pada sampah yang berasal dari penerbangan internasional, terutama sampah sisa makanan yang mengandung hewan atau produk hewan.
Beberapa bakteri Enterobacteriaceae dalam penelitian ini ditemukan pada sampel keju, ayam, daging, dan krim seperti yang terlihat pada tabel 2. Tujuh puluh delapan sampel tersebut bervariasi dari daging yang diolah dengan berbagai cara (rolade daging, kari daging, burger daging, daging asap), daging ayam (ayam goreng, kari ayam, potongan ayam), yoghurt, susu (susu penuh, susu skim, sup krim susu), es krim, keju (salad dan keju, keju lembaran), mentega (roti dengan mentega, mentega).

Ditemukannya Salmonella Typhimurium sebagai bakteri patogen dari isolat Enterobacteriaceae menandakan bahwa bakteri ini dapat menjadi sumber kontaminasi ke lingkungan. Salmonella enterica serovar Typhimurium (Salmonella Typhymurium) adalah patogen utama pada saluran usus manusia dan hewan. Pada manusia, bakteri ini menyebabkan penyakit gastroenteritis. Sebagai bakteri tular pangan, infeksi bermula dari masuknya bakteri ini melalui makanan atau minuman terkontaminasi hingga mencapai epitel usus dan memicu penyakit gastrointestinal. Salmonella Typhymurium dapat bertahan hingga 8 bulan pada keju cheddar yang disimpan pada suhu dingin (Fàbrega dan Jordi 2013). El-Baz et al. (2017) menyatakan kehadiran Salmonella pada sampel susu dan keju di Mesir, yang menandakan bahwa produk susu dari susu mentah dapat berpotensi sebagai sumber infeksi Salmonella. Serraino et al. (2012) menyatakan bahwa kunci utama untuk menurunkan risiko infeksi Salmonella Typhymurium yang berasal dari susu mentah adalah penerapan prinsip higienitas lingkungan dan pribadi untuk meminimalisasi kontaminasi, serta prosedur penyimpanan yang benar dari keju pada suhu dingin. Salmonella Typhymurium pada penelitian ini ditemukan pada keju. Terdapat kemungkinan bahwa keju tersebut berasal dari susu mentah atau kurang baiknya penyimpanan keju pada fasilitas pendingin di pesawat.

Beberapa bakteri yang ditemukan memiliki resistensi cukup tinggi terhadap Nalidixic Acid yaitu sebesar 57\%. Nalidixic Acid merupakan obat yang 
sering digunakan di masyarakat tanpa resep dokter karena dijual bebas. Resistensi terhadap fluroquinolone telah menjadi masalah sejak Nalidixic Acid dimasukkan ke dalam pengobatan klinis lebih dari 40 tahun yang lalu. Nalidixic Acid merupakan fluoroquinolone pertama yang banyak digunakan, ditemukan secara kebetulan sebagai produk sampingan dari sintesis fluoroquinolone. Nalidixic Acid sering digunakan untuk mengobati infeksi saluran kemih pada manusia (Jacoby 2005).

Antibiotik adalah salah satu pengobatan yang paling sering digunakan untuk mengobati penyakit. Selain untuk pengobatan medis pada manusia, antibiotik digunakan secara luas pada peternakan dan pertanian. Limbah yang berasal dari manusia, pertanian dan peternakan dapat mengandung antibiotik dan gen resisten antibiotik ini dapat mengontaminasi lingkungan. Resistensi antibiotik adalah pengurangan efektivitas dari pengobatan yang menggunakan antimikrobial terhadap suatu penyakit (Shaikh et al. 2015).

Untuk bertahan hidup, bakteri mengembangkan cara yang kompleks dan stategis untuk menahan serangan antibiotik. Resistensi antibiotik telah berkembang cepat dalam beberapa dekade terakhir dan menjadi salah satu perhatian dalam kesehatan masyarakat. Infeksi bakteri yang sukar diobati karena MDR juga telah menjadi semakin umum ditemui saat ini (Munita dan Arias 2016). Bakteri telah mengembangkan mekanisme untuk menangkal antibiotik. Gen yang mengkode mekanisme pertahanan tersebut terletak pada kromosom bakteri atau plasmid ekstrakromosomal dan kemudian diteruskan ke generasi berikutnya (vertical gene transfer). Elemen genetik seperti plasmid dapat ditukarkan antar bakteri yang berbeda toksonominya (horizontal gene transfer). Tranfer gen horizontal dapat ditemui pada bakteri yang kepadatan dan diversitasnya tinggi seperti di saluran limbah (Schwartz et al. 2003).

Pemakaian antibiotik dengan dosis yang tidak sesuai menimbulkan kekhawatiran akan meningkatkan kasus resistensi antibiotik dan menyebabkan multiresisten. Multiresisten atau Multiple Drugs Resistance (MDR) didefinisikan sebagai resistensi terhadap dua atau lebih obat maupun klasifikasi obat (Van Duin et al. 2014). Jenis yang sangat membahayakan kesehatan masyarakat adalah bakteri multiresisten terhadap beberapa antibiotik. Multiresisten dapat terjadi bila bakteri telah resisten terhadap 3 atau 5 antibiotik (Jametz et al. 2014).
Beberapa bakteri dari golongan Enterobacteriaceae dapat bertindak sebagai sumber zoonosis yang dapat menular ke manusia melalui kontak kulit dengan hewan yang terinfeksi, air yang terkontaminasi, atau dengan konsumsi makanan atau sayuran yang terkontaminasi. Enterobacteriaceae pada penelitian ini telah mengalami MDR paling banyak terhadap 2 golongan antibiotik 38\% yaitu golongan Fluroquinolone dan Cephalosporin. Hal ini karena penggunaan 2 golongan antibiotik ini yang tidak terbatas di kalangan masyarakat.

Beberapa penelitian yang dilakukan pada skala laboratorium ditemukan fakta bahwa hanya sedikit senyawa antiobiotik yang dapat diuraikan di lingkungan. Genotoksisitas dari senyawa quinolones dan metronidazole tidak dapat hilang. Quinolones menyerap secara sempurna pada limbah selokan, tanah dan sedimen. Bahkan pada sedimen, quionolones tidak dapat diuraikan. Kurang dari $1 \%$ dari sarafloxacin, jenis fluoroquinolone yang disetujui untuk pencegahan penyakit pada penyakit unggas, dapat dieliminasi pada lapisan tanah setelah 80 hari. Hal ini disebabkan oleh keterikatannya yang tinggi ke tanah. Virginiamycin, pakan tambahan yang mengandung antiobiotik biasa diberikan secara oral sebagai promotor pertumbuhan di peternakan. Jenis ini ditemukan dapat diuraikan dalam tanah. Cyclosporin juga dapat diuraikan, tetapi membutuhkan waktu beberapa bulan dalam sampel tanah basah. Beberapa penemuan tersebut mengindikasikan bahwa metode penguraian substansi antibiotik di lingkungan bukan merupakan pilihan untuk menghilangkan residu antibiotik secara total. Konsentrasi antibiotik yang tinggi di air limbah yang digunakan dari pertanian dan peternakan memiliki dampak nyata ke lingkungan perairan (Kümmerer 2003).

Bakteri patogen yang resisten bahkan multiresisten telah ditemukan di air limbah dan lingkungan secara umum. Air limbah yang mengandung bakteri resisten serta antibiotik yang masuk dalam irigasi dan selokan digunakan dalam pertanian dan peternakan, selanjutnya dapat masuk ke dalam rantai makanan secara langsung. Resistensi dapat ditranfer ke bakteri lain yang hidup bersama di lingkungan seperti air tanah atau air minum. Selain itu senyawa aktif dari antibiotik dan sediaan farmasetik yang disekresikan ke lingkungan relatif tidak berubah (Kümmerer 2003). Berdasarkan hal tersebut, ada kemungkinan bakteri dari sampel sisa makanan ini, yang telah mengalami resistensi bahkan multi 
resisten dapat masuk ke saluran air sekitar tempat pembuangan maupun tempat pengumpulan sampah sebelum dibuang.

Berdasarkan hasil pengamatan di lapangan, ditemukan ada 3 cara pengelolaan sampah internasional dari pesawat. Pertama, sampah tidak diturunkan di $\mathrm{BISH}$, tetapi dibawa kembali ke negara asal. Kedua, sampah diturunkan di BISH dan dibawa langsung ke incinerator untuk dimusnahkan. Ketiga, sampah dikelola oleh pihak katering dan dibawa ke tempat pembuang akhir (TPA) di Tangerang.

Cara ketiga mengandung risiko penyebaran bakteri yang resisten pada lingkungan. Dalam perjalanannya menuju TPA, sampah dicampur dengan sampah dapur dan sampah perkantoran di lingkungan perusahaan catering yang bersangkutan. Risiko lain yang lebih penting adalah sampah makanan tersebut menjadi pakan hewan di sekitar TPA. Sampah dan sisa makanan pesawat saat ini banyak dimanfaatkan sebagai pakan ternak, dan masih memiliki nilai ekonomis yang dimanfaatkan oleh masyarakat. Menurut United State Departement of Agriculture (USDA 2012), sampah yang dapat didaur ulang hanyalah kaleng aluminium, gelas, atau plastik yang tidak digunakan untuk tempat susu dan produknya. Tindakan sterilisasi dan pembakaran diperlukan untuk sampah yang digunakan untuk susu dan produknya. Untuk sampah lain seperti karton dapat didaur ulang bila tidak digunakan atau bersentuhan langsung dengan hewan atau produk hewan. Sampah yang dapat didaur ulang ini juga harus terpisah dengan limbah sisa makanan.

Pemahaman yang berbeda mengenai sampah internasional antara pengelola bandara, petugas karantina, dan masyarakat umum perlu diseragamkan. Sampah internasional harus dipahami sebagai sampah yang tidak bisa dimanfaatkan dan tidak bisa didaur ulang. Kesadaran masyarakat untuk memperlakukan sampah internasional sebagai sampah yang harus diperlakukan khusus dapat dibangun melalui edukasi mengenai bahaya penyebaran penyakit akibat sampah tersebut. Perubahan cara pandang dan gaya hidup masyarakat terutama masyarakat yang berada di sekitar bandara (pekerja airlines, pekerja darat, dan masyarakat umum) membutuhkan kerja keras dari semua pihak. Petugas karantina yang bertanggung jawab terhadap pengawasan sampah internasional, petugas bandara yang berhubungan langsung dengan sampah internasional dan banyak pihak lain.

Di Indonesia saat ini, risiko penyebaran penyakit melalui SI belum menjadi bagian penting dari mana- jemen bandara. Fakta bahwa SI dapat menyebarkan bakteri yang resisten terhadap antibiotik tidak dapat diabaikan. Menurunkan risiko penyebarannya melalui sampah pesawat udara harus menjadi perhatian seluruh lapisan manejemen pengelola bandara, serta penumpang, sehingga Enterobacteriaceae yang terdapat di sisa makanan ini kemungkinan berasal dari penumpang atau makanan yang disajikan dalam pesawat.

Kesimpulan yang diperoleh dari penelitian ini adalah tingkat resistensi Enterobacteriaceae cukup tinggi ditemukan pada isolat Enterobacteriaceae dari sampel pangan asal hewan pada sampah internasional di Bandara Internasional Soekarno Hatta (BISH). Isolat Enterobacteriaceae tersebut telah mengalami Multidrug Resistence (MDR) terhadap 2 golongan antibiotik (38\%), 3 golongan antibiotik (10\%), 4 golongan antibiotik (3\%).

\section{UCAPAN TERIMA KASIH}

Terima kasih kepada Badan Karantina Pertanian untuk pemberian beasiswa tugas belajar S3 di IPB. Ucapan terima kasih juga penulis haturkan untuk jajaran struktural dan pegawai di Balai Besar Karantina Pertanian Soekarno Hatta, Balai Besar Uji Standar Karantina Pertanian, serta Balai Uji Terap Teknik dan Metode Karantina Pertanian. Terima kasih juga diucapkan kepada Laboratorium Kesehatan Masyarakat Veteriner Fakultas Kedokteran Hewan IPB.

"Penulis menyatakan tidak ada konflik kepentingan dengan pihak-pihak yang terkait dalam penelitian ini".

\section{DAFTAR PUSTAKA}

Adiati RR, Rahardyan B. 2012. Estimasi kondisi eksisting sebagai dasar rancangan Eco Airport Bandar Udara Soekarno Hatta. [Skripsi]. Bandung (ID): Program Studi Teknik Lingkungan Fakultas Teknik Sipil dan Lingkungan ITB.

[API] Analytical Profile Index. 2018. API 20E kit. APIWEB $^{\text {TM }}$. BioMe'rieux, Marcy l'Etoile, Franc. https://apiweb.biomerieux.com/servlet/Authentic ate?action=prepareLogin. Download: Juli 10, 2018

Abera B, Yitayew G, Amare H. 2016. Salmonella serotypeTyphi, Shigella, and intestinal parasites among food handlers at Bahir Dar University, Ethiopia. Journal Infection Dev Ctries. 10(2): 121-126. 
[BPS] Badan Pusat Statistik. 2017. Statistik Transportasi Udara (Air Transportation Statistik). 2017.https://www.bps.go.id/publication/2018/11/2 7/c5a66561bc763984bed341db/statistiktransportasi-udara-2017.html. Download: January 5, 2018

[BSN] Badan Standardisasi Nasional, Indonesia. 1994. Standar Nasional Indonesia (SNI) 19-39641994. Metode pengambilan dan pengukuran contoh timbulan dan komposisi sampah perkotaan.

[BSN] Badan Standardisasi Nasional, Indonesia. 2008. Standar Nasional Indonesia (SNI) 2897:2008 Metode pengujian cemaran mikroba dalam daging, telur dan susu, serta hasil olahannya.

[CFIA] Canadian Food International Agency. 2012. International waste directive. www.inspection. gc.ca/animals/terrestrialanimals/imports/policies/ general/2002-17/eng/1321050654899/1323826743 862\#intro. Download: June 20, 2017

El-Baz AH, El-Sherbini $M$, Abdelkhalek A, AlAshmawy MA. 2017. Prevalence and molecular characterization of Salmonella serovars in milk and cheese in Mansoura city. Egypt Journal Advanced Veterinary Animal Research. 4(1): 45-51.

Fàbrega A, Jordi V. 2013. Salmonella enterica Serovar Typhimurium skills to succeed in the host: Virulence and regulation. Clinical Microbiology Review. 26 (2): 308-341.

Hartnett E, Adkin A, Seaman M, Cooper J, Watson E, Coburn H, England T, Marooney C, Cox A, Wooldridge MA. 2017. Quantitative assessment of the risks from illegally imported meat contaminated with foot and mouth disease virus to Great Britain. March 2007. Risk Analysis. 27(1): 187-202.

Humphries RM, Linscott AJ. 2015. Laboratory Diagnosis of Bacterial Gastroenteritis. Practitioner Guide for Clinical Microbiology Review. Cumitechs. 28:1

[IATA] International Air Transport Association. 2014. Airline cabin waste. https://www.iata.org/policy/ environment/Pages/cabin-waste.aspx. Download: June 20, 2017

Janet A. 2018. CLSI subcommittee on antimicrobial susceptibility testing Vol 3. https://clsi.org/ media/2270/clsi_astnewsupdate_june2018_final.pdf. Download: June 20, 2019
Jametz, Stephen AM, Brooks GF. 2005. Mikrobiologi Kedokteran. Alih Bahasa. Muhadihardi E, Kuntaman, Wasito EB et al. Jakarta (ID): Salemba Medika.

Jacoby GA. 2005. Mechanisms of resistance of Quinolones. Clinical Infectious Disease. 41(2): S120S126.

Kümmerer K. 2003. Significance of antibiotik in the environment. Journal Antimicrobiology Chemotheraphy. 52(1): 5-7.

Kulczyński $M$, Tomaszewski $M$, Łuniewski $M$, Olender A. 2017. Air transport and the spread of infectious diseases. World Science News. 76:123135. EISSN 2392-2192.

Munita JM, Arias CA. 2016. Mechanisms of antibiotik resistance. Microbiology Spectrum. 4(2): VMBF0016-2015. doi:10.1128/microbiolspec.VMBF-00162015

Schwartz T, Kohnen W, Jansen B, Obst U. 2003. Detection of antibiotik-resistant bacteria and their resistance genes in wastewater, surface water, and drinking water biofilms. FEMS Microbiology Ecology. 43(2003): 325-335.

Serraino A, Finazzi G, Marchetti G, Daminelli P, Riu R, Giacometti F, Losio MN, Rosmini R. 2012. Behaviour of Salmonella Typhimurium during production and storage of artisan water buffalo Mozzarella cheese. Italian Journal Animal Sciene. 11(e53): 285-289.

Shaikh S, Fatima J, Shakil S, Rizvi SMD, Kamal MA. 2014. Antibiotic resistance and extended spectrum beta lactamases: types, epidemiology and treatment. Saudi Journal Biology Science. 22: 90101.

[USDA] United States Departement of Agriculture. 2015. Procedure for airports to request APHIS approval to receive international commercial passenger aircraft or international commercial cargo aircraft. https://www.aphis.usda.gov/import.../Internation alCommercialPassengerCargo.pdf. Download: June 20, 2017

Van Duin D, Cober E, Richter S. 2014. Tigecycline therapy for carbapenem-resistant Klebsiella pneumoniae (CRKP) bacteriuria leads to tigecycline resistance. Clinical Microbiology Infection. 5(2): 556-776 